\title{
Govêrno e Administração do Estado da Guanabara
}

\author{
Araujo Cavalcanti
}

Consagrada em textos constitucionais desde 1891, como imperativo de integração e segurança do Estado, a transferência da Capital da República para o Planalto Central não poderia deixar de figurar em posição de relêvo entre os objetivos básicos do Govêrno Federal e dos Podêres Constituidos, em geral Essa relevante aspiração nacional é, hoje, incontestàvelmente, uma resplêndida realidade, consubstanciada em fatos concretos que, por sua vez, representam fatôres positivos de transfiguração política, demográfica, social, econômica e administrativa do Pais - através da integração efetiva do «Brasil Interior» na comunidade nacional. Como é do conhecimento geral a transfierência da Capital foi levada a efeito em meio a dificuldades aparentemente insuperáveis, sendo a construção de Brasilia, de fato, uma decorrência direta e imediata das decisôes inflexiveis tomadas pelo Govêrno e pelo Congresso Nacional. Logo de início, nos primeiros dias de set mandato, submeteu o então Presidente Juscelino Kubitschek, à aprovação do Congresso, Projetos de Lei dispondo sôbre a área da nova Capital e a constituição da Companhia Urbanizadora (Novacap), a que competiria realizar contratos e executar obras e serviços aquêle fim destinados. Em seguida, com surpreendente presteza, foram elaborados acôrdos e convênios com o Estado de Goiás, para desapropriação de imóvets nas áreas escolhidas e posterior incorporação destas ao dominio da União; os trabalhos de campo afetos à Companhia LIrbanizadora foram imediatamente iniciados de acôrdo com as diretrizes do Plano genialmente concebido pelo Engenheiro Lúcio Costa. A fim de dar plena e definitiva exectição à Lei $n^{\circ} 3.273$, de 1 de outubro de 1957 - que, em cumprimento do art. 4?. $\$ 3$ ? do Ato das Disposições Constitucionais Transitórias determina se transfira, em 21 de abril de 1960, a Capital da União para o novo Distrito Federal já delimitado no Planalto Central -, vem a Administração Federal incțementando vigorosamente a conclusão das obras essenciais do Plano-Pilôto e das vias de acesso à Sede do Govêrno. Os serviços de construção de Brasilia foram, na verdade, pràticamente iniciados em fevereiro 
de 1957, pela mencionada Companhia Urbanizadora criada pela Lei $n^{\circ} 2.874$, de 19 de setembro de 1956. E de justiça acentuar a celeridade que a Novacap pôde imprimir à sua ação executiva logrando criar as condições econômicas e materiais propícias à instalação da nova metrópole. Já agora prossegue, com ritmo satisfatório, a transf̣erência do Govêrno Central dentro dos esquemas traçados; paulatinamente, entratá em funcionamento a nova Sede da Administração Federal, vinculada a tôdas as regiōes do Pais por uma rêde ferroviária, rodoviária e aero viária, que se ramificará em tôdas as direçōes.

Todavia, como é natural, o impacto da mudança da Capital para Brasilia, atingiu profundamente o antigo Distrito Federal, transformado a 21 de abril de 1960, no Estado da Guanabara. Além dos problemas peculiares e obstáculos de tôda a ordem decorrentes da transferência da Capital - no ritmo e nos prazos que a caracterizaram -, o Rio de Janeiro, como tal entendido o ex-Distrito Federal - teve de enfrentar as conseqüências inevitáveis dessa mudança histórica. Operou-se uma transformação radical e profunda, surgindo a 21 de abril de 1960, com o recém-criado Estado da Guanabara, uma nova Unidade da Federação Brasileira.

A Revista do Serviço Público acompantou e divulgou com o máximo interêsse, nestes últimos anos, a marcha do magno empreendimento. Igualmente impottantes são os problemas de planejamento e organização do novo Estado, que se encontra em plena fase de estruturação jutidico-constitucional. Agora mesmo, no momento em que a Assembléia Legislativa ultima a elaboração de uma Constituição pata a Estado da Guanabara - uma Carta Magna realmente atualizada e adequada às necessidades do antigo Distrito Federal - recrudescem de intensidade os debates em tôtno dos mencionados problemas cujas proporções se ampliaram desmesuradamente, desafiando a inteligência, a cultura, o patriotismo e a capacidade criadora dos responsáveis pela elaboração da Lei Magna da nova Unidade Federativa, eleitos em outubro de 1960.

O Governador Provisório do Estado da Guanabara, Embaixador José Sete Câmara, não teve tempo material para equacionar e resolver tais problemas, em virtude das próprias caracteristicas de transitoriedade de sua gestão, limitado, como se encontrava, aos encargos mais urgentes de natureza administrativa e às responsabilidades de saneamento financeiro. No entanto, com exemplar senso de responsabilidade, deixou o terteno preparado e um vasto «dossier» de estudos, sujestões, projetos e subsidios do mais alto valor, para ser utilizado pelo seu substituto, o eminente primeiro Governador eleito da Guanabara, nas eleições de outubro p. passado, o ex-Deputado Carlos Lacerda. 
Ainda por ocasião do Govêrno Provisório, promoveu o «Correio da Manhã» a realização de um grande Simpósio - «Forum Paulo de Frontin» - encerrado a 28 de outubro de 1960, durante o qual foram reexaminadas em profundidade e inventariadas, através de lúcidos depoimentos, as soluções preconizadas para os múltiplos problemas do Estado da Guanabara. Aliás, pretende a «Revista do Serviço Público» publicar, oportunamente, as principais conclusões e debates do Inquérito promovido pelo "Correio da Manhã», o qual dedicou ao «Forum Paulo de Frontin» um Suplemento Especial (1 ${ }^{\circ}$ de dezembro de 1960). Convém ressaltar a importância, a amplitude e o significado excepcional dessa iniciativa do «Correio da Manhã»: - durante quatro dias, personalidades, técnicos e autoridades da mais alta expressão investigaram e debateram os problemas fundamentais de Govêrno e Administração do Estado da Guanabara.

O Temário organizado pela notável equipe do «Corteio da Manhã» orientou o «Forum Paulo de Frontin» no roteiro dos seguintes problemas básicos de Govêrno e Administração do Estado da Guanabara: I - Infra-Estrutura - Energia, transportes e comunicações, rêde de mercados e frigorificos, sistema portuátio, obras públicas básicas (citculação, água, esgotos, etc.); II - Politica para Fixação e Expansão da Indústria - salários e preços para os fatôtes de produção da área, com ênfase nos custos comparativos com as demais regiões concorrentes do Pais; medidas para criação de um parque de indústrias de base; financiamento da indústria de base; expansão do parque industrial; medidas financeiras e tributárias; politica de crédito para a industria local. III - Política para Desenvolvimento do Setor de Serviços - mercado financeiro intensificado das atividades ligadas às transações de titulos, ampliação do mercado de crédito e criação de um centro nacional promotor de investimentos; desenvolvimento das atividades comerciais; armazéns gerais; «wartants»; medidas para intensificar as funções de centro distribuidor inter-regional e internacional; criação de Feiras Permanentes, tanto para o mercado interno como para o mercado externo; Turismo; politica para ampliação das atividades culturais, de modo não só a incentivar o turismo (interno, principalmente) como expandir a hegemonia attual. IV - Entrosamento da Política Econômica do Estado nos Objetivos de Desenvolvimento Regional - politica fiscal como elemento de propulsão da economia regional; redução das despesas de custeio e de pessoal a um limite suportável; equacionamento dos problemas de transferência dos órgãos federais; politica de investimentos públicos; politica oficial de crédito para investimentos e financiamentos.

$A$ «Revista do Serviço Público», dando prosseguimento ao seu programa de investigação, debate e divulgação dos problemas 
nacionais básicos, notadamente no campo das atividades governamentais e administrativas, doutrinas, experiências e técnicas de maior significado e alcance para o Brasil - deliberou publicar, na presente edição, um documentário vinculado aos interêsses, problemas e reivindicações do Estado da Guanabara. Trata-se de uma colaboração da maior categoria, pelo seu mérito intrinseco, conteúdo técnico, valor informativo e inegável utilidade. Estas, as razões de ser da divulgação de «Govêrno e Administração do Estado da Guanabara» - contribuição do Professor e Técnico de Administração Araújo Cavalcanti. assiduo colaborador desta «Revista». Contribuição tanto mais importante quanto é certo tratar-se de um estudo pioneiro, e, até certo ponto, revolucionário, principalmente quando se verifica ter sido elaborado em 1956. De fato, foi precisamente no dia 9 de abril de 1956, às 20,00 horas, no recinto da antiga Câmara dos Vereadores, quando da solene instalação do II Congresso Pró-Autonomia e Reivindicações do Povo Carioca, que o Professor Araújo Cavalcanti submeteu ao exame e discussão dos convencionais então reunidos, o «Anteprojeto de Lei da Operação Guanabara» (Dispõe sôbre o Desenvolvimento Planificado do Distrito Federal e dá outras Providências). O lançamento da «Operação Guanabara» em 1956, pelo Professor Araúuo Cavalcanti, encaminhou, de maneira objetiva e com uma surpreendente antecipação de quatro anos, a formulação die um conjunto de soluções arrojadas para os problemas de Govêrno e Administração do então Distrito Federal e Capital da União. Com uma impressionante antecedencia de quatro anos, a «Operação Guanabara» consubstancionou e resumiu as principais conclusões do Inquérito realizado em outubro de 1960 pelo «Corteio da Manhã». Dai a natuteza prioritária, a singularidade e o sentido de renovação e pioneirismo do valioso trabalho ora publicado pela «Revista do Serviço Público». Conforme acentuou o Professor Araújo Cavalcanti, a 9 de abril de 1946, a «Operação Guanabara» resultou de um sério trabalho de pesquisa, análise e discussão das condições necessidades e reivindicações do Distrito Federal em função dos imperativos da mudança da Capital para o Planalto Central. a construção de Brasilia e a transformação do Distrito Federal - por fôrça de mandamento constitucional - no atual Estado da Guanabara - acontecimento histórico de transcendental importância para a Nação Brasileira, ocotrido, exatamente, a 21 de abril de 1960. O planejamento da «Operação Guanabara» correspondia às exigências politicas e técnicas de preparação do terreno, e elaboração de uma Politica de Desenvolvimento Global do então Distrito Federal, tendo em vista o advento de uma nova Unidade Federativa. A fim de atingit êsses objetivos, organizou o Professor Araújo Cavalcanti um Grupo de Trabalho constituido pelos Srs. Francisco Burkinski, Francelino de Araújo Gomes, Erasmo Martins Pedro e 
Wilton M. Coragem - Economistas e Técnicos de Administração de mérito incontestável, valores autênticos e comprovada experiência. Os acontecimentos posteriores estão demonstrando o acêrto, o arrôjo e a perenidade da «Operação Guanabara». Os inúmeros leitores e assinantes da «Revista do Serviço Público» poderão avaliar, em tôda sua extensão, a importância e utilidade da magnifica contribuição - patriótica e desinteressada - dêsses ilustres brasileiros.

(Nota da Redação).

\section{INTRODUÇÃO}

A

mais nova Unidade da Federação Brasileira não é mais Sergipe, mas - recém-criado Estado da Guanabara onde, a partir de 1763, durante quase dois séculos, se instalou a Sede do Govêrno Brasileiro. Denominado, no Império, Município Neutro, com a República, passou à categoria de Distrito Federal até ser efetivada a transferência da Capital para o Planalto Central, em Brasília, a 21 de abril de 1960. De acôrdo com os dados do Instituto Brasileiro de Geografia e Estatística (I.B.G.E.) mede 1.171 quilômetros quadrados a áréa terrestre no novo Estado, dos quais $640 \mathrm{~km}^{2}$ formam o quadro rural, $349 \mathrm{~km}^{2}$ o quadro suburbano e $182 \mathrm{~km}^{2}$ o quadro urbano. Estende-se seu território desde a ilha de' Pancaraiba, no extremo norte, até a ilha rasa de Curatiba, no extremo sul. Ainda consoante o I.B.G.E., o local de maior altitude é o maciço de Pedra Branca, com 1.024 metros; mas, considerando-se a zona habitada, Paineiras, com 460 metros, é o lugar mais elevado. As várias publicações do IBGE mostram, entre inúmeras outras peculiaridades, que o Estado da Guanabara se distingue das demais Unidades da Fe'deração por seu insignificante e decrescente espaço agrícola, simultâneamente com uma rápida e substancial expansão industrial. A área de lavoura diminuiu, entre 1940 e 1950 , de 30.000 (trinta mil) para 2.000 (dois mil) hectares. Entretanto, no mesmo periodo, o número de estabelecimentos fabris cresceu de 4.169 para 5.693 e o efetivo de operários industriais, de 123.459 para 171.463. Já em 1957 a indústria carioca contribuia com cota superior a $11 \%$ (onze por cento) do valor global da produção industrial do País. A população recenseada atingia, a 1 de julho de 1950 , o total de 2.377.451 com uma densidade demográfica calculada, na mesma data, em $1.753,28 \mathrm{ha} . / \mathrm{km}^{2}$. As estimativas da população para 1960 ultrapassavam o total de 3.500 .000 (três e meio milhões de habitantes). Dispensamo-nos de apresentar, nesta Introdução, a caracterização estatística do Estado da Guanabara, por ser desnecessário alongar o presente trabalho com a reprodução dos dados numéricos do conhecimento geral, através das publicaçôes especializadas do I.B.G.E.

O que nos interessa acentuar, no quadro das realidades do Estado da Guanabara, é o panorama global dos seus problemas fundamentais de Govêrno e Administração. 
A êste respeito merecem registro especial as indicações condensadas pelo eminente Professor José Arthur Rios quando de sua campanha, em outubro de 1960, para deputado constituinte. Nessa oportunidade o integro e conhecido sociólogo patrício resumiu, com objetividade e clareza, os elementos de uma planificação adequada aos supremos interêsses da CidadeEstado e de seus habitantes, preconizando, acima de tudo, «soluções humanas e justas», assim condensando o seu programa de ação imediata:

«1) O Plano Diretor da Cidade, Lei Básica que imprimirá sentido democrático ao crescimento urbano e dará condições de vida mais favoráveis aos habitantes da Guanabara.

2:) O planejamento das atividades econômicas de modo a proteger - consumidor pela melhoria da produção e distribuição, pela coordenação da iniciativa pública e privada.

39) Politica de estímulo e apoio à aquisição de casa própria e da pequena propriedade rural.

$4^{\circ}$ ) Recuperação da população favelada pela educação e o planejamento urbano.

5\%) Amparo ao lavrador e criação de núcleos hortigranjeiros.

6:) Ampliação e melhoria do sistema educacional e dos serviços médicosanitários face às necessidades sociais e econômicas do Rio de Janeiro.»

Finalmente, cumprimos o dever de manifestar, nesta Introdução, os nossos profundos agradecimentos aos insignes Professôres Francisco Burkinski, Conselheiro da Associação Brasiléira de Municipios e renomado Jurista; Engenheiro Francelino dE Araújo Gomes, Economista e Estatístico; Vereador Erasmo Martins Pedro, ex-Secretário de Estado; e Advogado. Wilton M. Coragem, Chefe de Serviço da antiga P.D.F. todos profundos conhecedore's dos problemas de Govêrno e Administração da Terra Carioca. A «Operação Gtıanabara» que a seguir transcrevemos, tem, como finalidade primordial a destinação de preparar o advento de uma Política de Emancipação Global e Desenvolvimento Planificado para a mais nova Unidade da Federação Brasileira - Araújo CavalCanti, Técnico de Administração do Govêrno Federal.

\section{OBjETIVOS E CARACTERÍSTICAS}

Operação Guanabara foi a expressão sintética encontrada para designar um conjunto orgânico de projetos, iniciativas e providências que se sugere sejam emanadas dos podêres executivo e legislativo da Cidade do Rio de Janeiro, tendentes a acelerar o desenvolvimento econômico e social do Distrito Federal. De acôrdo com o art. $4^{\circ}, \S 4^{\circ}$, do Ato das Disposiçóes Transitórias da Constituição Federal de 1946, uma vez transferida a Capital da União para o Planalto Central do País, o atual Distrito Federal passará a constituir o Estado da Guanabara. Não foram pois razões subjetivas que preestabeleceram o uso da expressão Operação Guanabara. Trata-se de um plano de desenvolvimento econômico e social a ser aplicado a uma régião com caracteristicas especificas e designação própria. 
No III Congresso Nacional de Municipios, realizado em maio de 1954, em São Lourenço, Minas Gerais, foi aprovada, por unanimidade das delegações presentes, uma recomendação especial que esboçou as linhas gerais do Plano Nacional de Obras e Serviços Municipais (Operação Municipio). Atendendo a essa imposição do Interior, a 25 de junho de 1954 , o Senador Jarbas Maranhão apresentou um projeto de lei que dispõe sôbre a organização das bases e diretrizes da Operação Municipio.

Já no I Congresso dos Municipios Fluminenses, promovido de 17 a 21 de' agôsto de 1955, em Niterói, pela Sociedade Amigos dos Municípios, foi aprovado, sob vivas aclamações, um plano de desenvolvimento econômico e social dos municipios fluminenses (Operação Rio de Janeiro). Êsse plano constitui a primeira projeção regional da Operação Municipio de âmbito nacional. A Operação Cabo Frio, aprovada na I Reunião dos Municípios da Zona de Cantagalo e adjacências, também realizada pela Sociedade Amigos dos Municípios, é a primeira projeção municipal da Operação Municipio. A Operação Guanabara constitui uma projeção específica, já que o Distrito Federal não é considerado nem Estado ne'm Municipio. Sua organização politica e administrativa é peculiar. Daí porque na elaboração do plano de desenvolvimento econômico e social do Distrito Federal foram utilizados subsídios tanto da Operação Rio de Janeiro, como da Operação Cabo Frio. O planejamento da Operação Guanabara teve inicio com a rigorosa investigação das condições peculiares do Distrito Federal. Os delineamentos. gerais da Operação Guanabara constituem um equacionamento amplo e exato dos problemas fundamentais da região.

Conforme está previsto, a Operação Guanabara em sua primeira fase deverá ser executada $\mathrm{em}$ cinco (5) anos consecutivos. Portanto, é precisoque haja continuidade na administração, para que atinja as suas finalidades. Eis por que a Operação Guanabara está estreitamente vinculada ao problema da autonomia do Distrito Federal. Ela será mais fàcilmente posta em execução, ou talvez só poderá ser mesmo executada com cabal êxito, desde que o Distrito Federal tenha um Prefeito eleito pelo povo, única maneira sem dúvida de se imprimir ritmo de continuidade à máquina administrativa. Com efeito, enquanto os prefeitos do Distrito Federal forem meros delegados de confiança do Presidente da República, jamais se poderá executar com real sucesso um plano qüinqüienal de' larga envergadura, já que a execução do mesmo importa em amplo apoio popular e estabilidade do chefe do executivo. Além disso, é da essência e da estrutura da própria Operação Guanabara a descentralização dos serviços, obras e empreendimentos iniciativa essa que implica na criação de subprefeituras, tendo-se em vista grupos de bairros, subúrbios e ilhas. E, como é sabido, as subprefeituras sòmente poderão alcançar plenamente seus objetivos, desde que surjam como decorrência da autonomia do Distrito Federal. Do contrário, os subprefeitos exercerão cargos de confiança do Prefeito é serão substituídos cada vez que o Presidente da República designar novos Prefeitos, o que vem acontecendo há anos, em média, de 18 em 18 meses.

Embora a Operação Guanabara seja considerada uma projeção regional da Operação Municipio, nada impede possa ser executada isoladamente. 


\section{Instrumentos legais da Operação Guanabara}

A Operação Guanabara tem por objetivo primordial apressar o desenvolvimento econômico, social e cultural do Distrito Federal, mediante investimentos geradores de riqueza e de melhoria das condições de vida do povo carioca. Para isso ela provocará a movimentação dé tôdas as engrenagens do govêrno e da administração do Distrito Federal, ampliando e fortalecendo, de maneira surpreendente, as elevadas funções do Prefeito e dos Vereadores, uma vez que, como décorrência da Opleração Guanabara, o Prefeito deverá baixar os atos complementares previstos e a Câmara Municipal votar uma série de leis. Com efeito, sancionada a Operação Guanabara, competirá ao governador da cidade entre outras tarefas, a ampliação e fortalecimento das atividades do Departamento de Urbanismo da Secretaria de Viação e Obras Públicas, incumbido de organizar o Plano de Desenvolvimento Econômico e Social do Distrito Federal (Operação Guanabara); a revisão e modernização do Plano Diretor; a execução das obras previstas no Plano Diretor da Rêde do Metropolitano; a formulação do Plano de Obras, Serviços e Empreendimentos, acompanhado das respectivas tabelas discriminativas, estimativa de custo e orçamentos analíticos; o estabelecimento de' um sistema multilateral de acôrdos, convênios e contratos; a expedição de normas ou quaisquer medidas instituídas pelo Sistema de Atos Complementares; a racionalização do aparelhamento governamental e administrativo. mediante reformas de base e processos de descentralização, simplificação e modernização; contrair empréstimos destinados ao custeio e financiamento da Operação Guanabara, nos têrmos, condições, volume e prazo fixados pela Lei Financeira; contratar ou organizar uma Comissão Técnica destinada a proceder à revisão do sistema tributário e elaboração do respectivo Código; instituir a Administração da Operação Guanabara, para executar e coordenar as obras, empreendimentos e serviços que a integram; baixar os atos necessários à estrutura e funcionamento da Administração do Plano e, por fim, expedir o Regulamento da Operação Guanabara. À Câmara do Distrito Federal caberá a votação da Lei Financeira constituida de' recursos vinculados às obras, empreendimentos, serviços e demais iniciativas que o plano vier a abranger; a votação de leis especiais que a aplicação, revisão periódica, desdobramentos, adaptações ou modificações do plano e respectivos projetos exigirem e a votação da Lei Especial relativa ao sistema financeiro da execução dos projetos vinculados à Operação Guanabara.

Do conjunto das medidas legislativas se destaca a Lei de Planificação do Distrito Federal. Essa lei deverá estabelecer as normas jurídicas e o regime de funcionamento da Operação Guanabara, tendo em vista as obras, empreendimentos e serviços em geral, destinados ao desenvolvimento econômico e social do Distrito Federal, e o Plano Diretor com vistas à sede, bairros, subúrbios, zona rural e ilhas, em especial. Ademais, a referida lei prefixará os prazos e discriminará as metas numéricas a serem atingidas (quilômetros, quilowatts, metros cúbicos, etc.); conterá entre outros, dispositivos sôbre a reorganização administrativa da municipalidade; racionalização tributária e codificação em geral. 
De todo o conjunto acima especificado de atos administrativos e providências legislativas advirão enormes benefícios à população carioca, já que criados estarão novos instrumentos pelos quais se procurará solucionar os problemas essenciais do Distrito Federal.

\section{Problemas fundamentais do Distrito Federal}

A Operação Guanabara classifica genèricamente os problemas básicos do Distrito Federal, indicando as iniciativas mais adequadas à sua solução.

Com a execução das obras, serviço e empreendimentos, destinados sobretudo ao desenvolvimento econômico e social, se colima solucionar gradualmente os problemas fundamentais do Distrito Federal, tais como, entre outros, 0 da industrialização descentralizada; iniciativas p:oneiras de energia atômica; reorganização agrária e aproveitamento das áreas improdutivas; ampliação e modernização dos sistemas de transportes; ampliação da rêde telefônica: melhoria das condições de vida e elevação dos niveis culturais da população; saneamento e. urbanismo; exploração industrial do turismo; estudos e levantamentos; pesquisas, investigações científicas e tecnológicas; produtividade; assistência social. A Operação Guanabara fixa as obras e serviços destinados a solucionar os problemas acima apontados.

Através do Plano Diretor se tem em mira atingir a gradual e eficiente solução de problemas urbanos, suburbanos e' da zona rural, consistentes, primordialmente, no abastecimento d'água; transporte coletivo; contrôle das inundações; extensão da rêde dé esgotos sanitários às áreas suburbanas e rural; habitações populares; aproveitamento do lixo; tráfego urbano; chácaras, hortas e granjas do "cinturão verde», para alimentação do povo; matadouros e frigoríficos; mercadinhos e feiras-livres; entrepostos; pavimentação, calçamento, túneis e viadutos; hospitais e casas de saúde; maternidade; colonização em bases cooperativas; bosques e hortos florestais; parques e jardins; campos de esporte; hotéis e vários outros. Diversas fontes de recursos financeiros serão aproveitadas para atingir as metas preconizadas pela Operação Guanabara.

\section{Financiamento da Operação Guanabara}

A Operação Guanabara constituirá um Anexo Especial do Orçamento Geral do Distrito Federal, e o seu financiamento será atendido à conta de múltiplos recursos, dentre os quais se destacam a percentagem da arrecadação dos impostos de vendas e consignações, predial e territorial, nos têrmos de regulamentação a ser promovida pela Prefeitura; o produto da contribuição de melhoria; o produto do aumento da arrecadação conseqüente à revisão e modernização do sistema tributário; as rendas oriundas de acôrdos com emprêsas privadas; operações de crédito, indenização do Govêrno Federal pela mudança da Capital. 


\section{Conclusões}

Tudo indica que a Operação Guanabara atende plenamente aos anseios das populações urbanas, suburbanas e da zona rural do Distrito Federal. $\mathrm{E}$, uma vez que mais fàcilmente será executada, ou talvez, sòmente poderá ser executada a partir do momento que se conquistar a efetiva autonomia do Distrito Federal, cumpre empreender todos os esforços no sentido da obtenção, no mais breve prazo possivel, daquela reivindicação máxima do povo carioca.

\section{METAS PREFERENCIAIS}

\section{(Politicas, Administrativas, Econômicas e Sociais)}

I - Autonomia do Distrito Federal - Cumprimento das resoluções aprovadas no II Congresso Pró-Autonimia e Reivindicações do Povo Carioca.

II - Estado da Guanabara - Antecipar a mudança da Capital da União para o Planalto Central do País e preparar désde já as bases e as condições em que se fará a transformação do Distrito Federal em Estado da Guanabara;

Entendimentos com o Govêrno Federal para pagamento de uma indenização especial pela mudança da Capital Federal para o Planalto Central do Pais.

Fixação de um teto mínimo para a referida indenização, na base de $50 \%$ dos investimentos totais estimados para o qüinqüênio da Operação Guanabara.

Acôrdo com o Govêrno Federal para o pagamento da indenização prevista no prazo de 10 anos.

III - Abastecimento d'água - Conclusão da segunda e terceira etapas das obras da adutora do Guandu e subadutoras, as quais permitirão o fornecimento de 1 bilhão e 200 milhõe's de litros de água diários à população carioca.

Revisão e ampliação da rêde distribuidora de água, para receber o refôrço da adutora do Guandu.

Construção dos reservatórios de água de Vila Alegre, Bangu, Acarí, Leblon, Bispo e Engenho Novo.

IV - Transporte coletivo e tráfego - Construção de pelo menos 10 quilômetros da rêde do metropolitano, calculada ém 42 quilômetros, se adotado o plano francês.

Construção dos túneis Rio Comprido a Cosme Velho (450 metros) e Cosme Velho a Lagoa (1.900 metros).

Conclusão do viaduto da Rua Ana Néri.

Conclusão do desmonte do Morro de Santo Antônio.

Início da construção do viaduto do Trevo do Galeão. 
V - Obras Públicas - Construção de um canal interceptor partindo um pouco acima da Praça Saenz Peña, onde receberá as águas do curso superior do rio Trapicheiro, até sair no largo da Cancela e no Campo de São Cristóvão, donde seguirá até o mar (projeto elaborado na administração Henrique Dodsworth).

Abertura de avenidas, no fundo do vale edificado de Laranjeiras e no sopé das serras, no percurso desde a Garganta do Humaitá ao morro do Mundo Novo, de um lado, e pelos maciços da Saudade, São João e Pasmado, de' outro, avenidas essas destinadas a interceptar as águas das encostas facilitando a sua captação e condução direta ao mar (sugestão do Engenheiro Edison Passos).

Construção pela Prefeitura de usinas de asfalto.

VI - Saúde - Equipagem total da Maternidade de São Cristóvão.

Construção do novo hospital «Sousa Aguiar» no mesmo local onde funciona o Hospital de Pronto Socorro, conforme projeto elaborado pela Cocissão designada pelo ex-Prefeito Alim Pedro.

VII - Ensino - Construção de escolas primárias segundo projetos funcionais, em tôdas as zonas cuja população em idade escolar assim o exijam.

VIII - Lixo - Construção de usinas de aproveitamento, recuperação e incineração do lixo, na Gávea, Botafogo, São Cristóvão, Rio Comprido, Engenho de Dentro e Inhaúma.

IX - Abastecimento - Construção de um Mercado Central, a ser localizado na Avenida Brasil ou proximidades, tendo em vista que o prazo da exploração do Mercado Municipal termina em 1957, bem como de uma rêde de mercado nos principais bairros.

$\mathrm{X}$ - Comunicaçôes - Ampliação e automatização de tôda a rêde telefônica suburbana, suprimindo-se desde já as taxas que gravam as correspondentes ligações.

XI - Administração - Reorganização Administrativa integral do Distrito Federal; Descentralização e Projeções Locais.

Transformação do Rio de Janeiro num Centro Mundial de Ciência, Técnica é Cultura.

\section{ANTEPROJETO DE LEI}

Dispóe sôbre o Desenvolvimento Planificado do Distrito Federal e dá outras

$$
\text { providências }
$$

Art. 19. Fica o Poder Executivo autorizado a organizar e realizar a Operação Guanabara - projeção regional da Operação Municipio de âmbito nacional.

Art. 2: A Operação Guanabara compreende: I - Plano de Obras, Empreendimentos e Serviços; II - Sistema de Atos Complementares. 


\section{Natureza e fins}

Art. 3? A Operação Guanabara, conjunto orgânico de projetos, iniciativas e providências, tem os seguintes objetivos principais:

a) transformar as circunscrições do Distrito Federal - centro, bairros, subúrbios e ilhas, - em unidades de' sustentação e fatôres de desenvolvimento econômico e social da Região, mediante investimentos vinculados a projetos geradores de riqueza e de melhoria das condições de vida da população;

b) equacionar e dar solução objetiva aos problemas essenciais do Distrito Federal, de preferência à base de acôrdos, convênios, consórcios ou contratos multilaterais;

c) ampliar e fortalecer a capacidade econômica, financeira e administrativa do Distrito Federal;

d) atrair capitais privados e incentivar a organização de sociedades de economia mista; local;

e) reorganizar, dinamizar, modernizar e descentralizar a administração

f) racionalizar o sistema tributário, sanear as finanças e regularizar a administração orçamentária;

g) criar condições favoráveis e lançar as bases de transformação do Distrito Federal no Estado da Guanabara.

\section{Instrumentos legais}

Art. 5: Os objetivos colimados pela Operação Guanabara serão atingidos mediante:

a) ampliação e fortalecimento das atividades do Departamento de Urbanismo da Secretaria de Viação e Obras Públicas, incumbida de organizar o Plano de Desenvolvimento Econômico e Social do Distrito Federal (Operação Guanabara);

b) votação do Fundo Espécial constituido de recursos vinculados às obras, empreendimentos, serviços e demais iniciativas que a Operação Guanabara vier a abranger;

c) estabelecimento de um sistema multilateral de Acôrdos, convênios e contratos, na forma prevista pela presente Lei e Atos que lhes forem subseqüientes ou complementares;

d) votação de leis especiais que a ampliação, revisão periódica, desdobramentos, adaptações ou modificações da Operação Guanabara e respectivos projetos exigirem;

e) expedição de normas ou quaisquer medidas instituídas pelo Sistema de Atos Complementares;

f) votação da Lei Especial relativa ao sistema financeiro da execução dos planos e projetos da Operação Guanabara;

g) formulação do Plano de Obras, Empreendimentos e' Serviços, acompanhado das respectivas tabelas discriminativas, estimativas de custo e orçamentos analíticos; 
h) revisão e modernização do Plano Diretor da Cidade;

i) racionalização do aparelhamento governamental e administrativo do Distrito Federal, mediante reformas de base e processos de descentralização, simplificação e modernização.

\section{Fases}

Art. 69 A Operação Guanabara em sua primeira fase deverá ser executada em cinco exercícios consecutivos, obedecidos os principios é preceitos fundamentais da presente lei.

\section{Planificação Municipal}

Art. 7 ${ }^{\circ}$ O Sistema de Atos Complementares a que se refere o item II, do art. $2^{\circ}$, compreenderá, principalmente, as seguintes providências: I - Lei de Planificação; II - Comandos de Produtividade.

Art. $8^{\circ}$ A Lei de Planificação estabelecerá as normas jurídicas e o regime de funcionamento da Operação Guanabara tendo em vista dois. setores fundamentais: I - Obras, Empreendimentos e Serviços em geral, destinados sobretudo ao desenvolvimento econômico e social do Distrito Federal; II - Plano Diretor da Cidade (Programas Especiais de Melhoramentos Urbanos).

$\S 1^{\circ}$ A Lei de Planificação prefixará os prazos e discriminará as metas numéricas (quilowatts, quilômetros, metros cúbicos, toneladas, etc...) a serem atingidas, bem assim a localização de cada um dos empreendimentos, obras ou serviços integrantes da Operação Guanabara;

$\S$ 2: A Lei de Planificação, conterá, entre outros, dispositivos sôbre a reorganização administrativa da Municipalidade; racionalização tributária e codificação em geral.

\section{Comandos de Produtividade}

Art. 9: Os Comandos de Produtividade instituídos pelo Sistema de Atos Complementares visam acompanhar e fiscalizar a execução dos planos. e projetos da Operação Guanabara.

Parágrafo único. Além de outros objetivos que lhes venham a ser atribuídos deverão os Comandos de Produtividade, em regime de ampla cooperação com a iniciativa privada, implantar técnicas e métodos racionais de trabalho, tendo em vista a elevação dos indices de eficiência, rentabilidade e produtividade.

Art. 10. O Sistema de Atos Complementares abrangerá propostas, medidas le'gislativas, providências ou quaisquer iniciativas destinadas à plena execução das obras, empreendimentos e servïços em geral, e dos Programas Especiais de Melhoramentos Urbanos (Plano Diretor da Cidade), em especial. 


\section{Esquema básico}

Art. 11. A Operação Guanabara, para o efetivo desenvolvimento. econômico e social do Distrito Federal, mobilizará recursos tendo em vista. resolver os seguintes problemas básicos:

a) eletrificação e industrialização descentralizada;

b) reorganização agrária e aproveitamento das áreas improdutivas: (zona rural do Distrito);

c) ampliação e modernização dos sistemas de transporte;

d) ampliação da rêde telefônica;

e) melhoria das condições de vida e elevação dos niveis culturais da população; assistência à maternidade e à infância; educação técnicoprofissional;

f) saneamento e urbanismo;

g) exploração industrial do turismo; recreação;

h) estudos e levantamentos; pesquisas, investigações científicas e. tecnológicas;

i) assistência social;

j) produtividade.

\section{Obras, Empreendimentos e Serviços}

Art. 12. Os objetivos gerais da Operação Guanabara serão atingidos pela solução gradual dos problemas básicos mencionados no artigo anterior, através das obras, empreendimentos e serviços abaixo discriminados:

19) expansão do parque industrial carioca; iniciativas pioneiras de energia atômica;

2:) eletrificação rural e dos bairros; refôrço do sistema de produção de energia elétrica para o Distrito Federal com o concurso da CEMIG através do aproveitamento da Usina geradora das Furnas no Rio Grande; refôrço do sistema de produção de energia elétrica da Light and Power, mediante construção de novas usinas geradoras, inclusive termelétricas, e das respectivas obras no Rio Paraiba; construção de usina atômica de $20.000 \mathrm{KW}$ mediante entendimentos com o Conselho Nacional de Pesquisas e órgãos especializados do Govêrno Federal;

3?) instalação de matadouros, frigoríficos, fábricas de fertilizantes, silos e armazéns; aquisição dos Armazéns Frigorificos na área do Cais do Pôrto;

4\%) unidades industriais para beneficiamento ou melhor aproveitamento da produção local;

$\left.5^{\circ}\right)$ usinas de asfalto; equipamento de pedreiras;

6\%) reorganização agrária, de molde a facilitar o acesso a propriedade; horticultura, pomicultura e floricultura; mecanização da lavoura (zona rural); 
$\left.7^{\circ}\right)$ implantação de esquemas de conservação de solos e reflorestamento, em regime de acôrdo com órgãos federais e emprêsas privadas;

$8^{\circ}$ ) empreendimentos de assistência à avicultura e à pecuária; aumento da produção forrageira; fomento animal;

9?) ampliação de postos agrícolas; fiscalização do comércio de mudas e sementes destinadas ao plantio no Distrito Federal;

10\%) revisão e modernização do cadastro rural; levantamento de cartas aerofotogramétricas e mapas pedológicos do Distrito Federal;

11\%) contrôle dos loteamentos;

12. financiamentos a longo prazo a proprietários, parceiros, arrendatários e posseiros (Decreto Federal n०22.010, de 20 de outubro de 1946);

13:) amparo aos trabalhadores rurais;

14\%) criação de uma rêde de habitações populares; parques proletários;

15\%) ampliação das escolas típicas rurais; incremento do ensino de nivel médio; construção de conjunto, constituído de teatro, galeria para exposições, bibliotecas e discotecas, a ser levantado no terreno da municipalidade, à Rua Evaristo da Veiga, com frente para a futura avenida Norte-Sul;

16:) centros, hospitais e demais serviços de saúde; equipagem da maternidade de São Cristóvão; funcionamento do Hospital Pedro Ernesto; postos de puericultura; ampliação do quadro de médicos e enfermeiras; creches;

17:) municipalização dos serviços funerários e cemitérios;

18:) estimulo à implantação de programas específicos de turismo; florestas e parques;

19) criação de centros de pesquisas, institutos de investigações cientificas e tecnológicas; estudos e levantamentos geoeconômicos e demográficos do Distrito Federal; conservação e defesa dos recursos naturais;

20.) transferência para a Prefeitura do Distrito Federal, mediante acôrdo com o govêrno federal, das obras e dotações da Cidade Universitária; construção em terrénos do atêrro da Glória, mediante convênio com o Centro Brasileiro de Pesquisas Físicas, dos prédios destinados a um Planetário e Museu de Ciências.

$21^{\circ}$ ) intensificação do serviço de limpeza e desobstrução das rêdes de canalização;

22:) contrôle contábil das emprêsas concessionárias;

23) articulação com a Comissão do Plano Diretor da Rêde do Metropolitano; execução das obras previstas no referido Plano Diretor;

24\%) aceleramento da execução do Plano Rodoviário do Distrito Federal;

$25^{\circ}$ ) instalação de maior número de telefones na zona suburbana;

26) elaboração e execução coordenada dos Programas Especiais de Melhoramentos Urbanos do Distrito Federal (Plano Diretor da Cidade) 
segundo escalas de prioridade e ordens de urgência preestabelecidas; fixação de metas numéricas preférenciais.

Art. 13. As obras, empreendimentos e serviços a que se refere o artigo anterior constituem a primeira fase da Operação Guanabara, sem prejuizo de outras providências, desde que se enquadrem nas finalidades previstas nos arts. $10,11,12,14$ e 15 , e se destinem a complementar, ampliar ou aperfeiçoar o Plano Geral de Desenvolvimento Econômico e Social do Distrito Federal tal como concebido e delineado pela Lei de Planificação (Obras, Empreendimentos e Serviços Municipais - Programas de Melhoramentos Urbanos - Plano Diretor; Comandos de Produtividade e demais iniciativas do Sistema de Atos Complementares).

\section{Plano Diretor da Cidade}

Art. 14. O Plano Diretor da Cidade, um dos setores da Operação Guanabara, constitui um conjunto integrado de melhoramentos urbanos a serem atingidos progressivamente, mediante aplicação concentrada de recursos financeiros e assistência técnica.

Art. 15. As obras, empreendimentos e serviços de primeira urgência e alta prioridade do Plano Diretor da Cidade, obedecerão ao seguinte escalonamento na solução dos problemas urbanos da sede, dos bairros e subúrbios: conclusão das obras da adutora do Guandu e subadutoras; revisão e ampliação da rêde distribuidora de água; metropolitano; transporte coletivo; contrôle das enchentes, extensão da rêde de esgotos sanitários às áreas suburbanas e rural; habitações populares e conjuntos residenciais; aproveitamento do lixo; ampliação da frota de caminhões de lixo; conclusão do cruzamento subterrâneo da Avenida Presidente' Vargas junto à estação D. Pedro II; contrôle do tráfego urbano, chácaras, hortas e granjas do «cinturão verde», para alimentação do povo; mercadinhos e feiras-livres; entrepostos; construção de túneis; pavimentação, calçamento, avenidas e viadutos; colonização em bases cooperativas; parques e jardins; bosques e hortos florestais; ampliação e aperfeiçoamento da rêde de escolas primárias; campos de esporte; hotéis; casas populares de cultura nos bairros; conchas acústicas destinadas a espetáculos ao ar livre; turismo.

\section{Projeções locais}

Art. 16. A Operação Guanabara far-se-á através de Projeções locais descentralizadas com denominação específica diférencial e recursos próprios, abrangendo a totalidade dos bairros, subúrbios e ilhas do Distrito Federal.

Parágrafo único. A cada Projeção Local da Operação Guanabara corresponderá determinado número de projetos, empreendimentos, obras e serviços devidamente coordenados.

\section{Investimentos - Lei Financeira}

Art. 17. Na organização da Operação Guanabara deverá ser observada, sempre que possivel, a técnica da municipalização das obras, empreendimentos e serviços. 
Art. 18. Aos Bancos e Emprêsas privadas idôneas, Cooperativas, Sindicatos, Associações Rurais, Industriais e Comerciais, fica assegurado o direito de colaborar ou participar na execução da Operação Guanabara, segundo cláusulas e condiçốes que forem estabelecidas pelo Sistema de Atos Comple'mentares.

Parágrafo único. A adesão de Bancos e Emprêsas privadas, Cooperativas, Sindicatos, Associações Rurais, Industriais e Comerciais, à Operação Guanabara, importa na aceitação das bases e diretrizes desta lei, bem assim dos princípios, fundamentos, normas e processos estabelecidos pelo Sistema de Atos Complementares.

Art. 19. A Lei Financeira da Operação Guanabara consignará os os recursos necessários à sua execução, tendo por base as seguintes prioridade's em relação às obras, empreendimentos e serviços:

a) maior rentabilidade;

b) maior interêsse econômico nacional, regional, urbano; e

c) maior interêsse social.

\section{Orçamento Especial}

Art. 20. A Operação Guanabara constituirá um Anexo Especial do Orçamento Geral do Distrito Federal, ao qual serão incorporados os auxílios e subvenções destinados às instituições privadas.

Parágrafo único. Ao referido Orçamento Especial, serão apensados os Orçamentos das Companhias, Sociedade Mistas ou Emprêsas que forem criadas para a plena realização da Operação Guanabara.

Art. 21. As despesas de custeio e os investimentos selecionados da Opleração Guanabara, na parte que constitui responsabilidade direta do Distrito Federal, serão estabelecidos e regulados em tôdas as suas modalidades pela Lei Financeira.

\section{Financiamentos}

Art. 22. O financiamento da Operação Guanabara será atendido à conta dos seguintes recursos:

a) totalidade da indenização a ser paga ao Distrito Federal pela União, ém consequiência da mudança da Capital Federal para o Planalto Central;

.b) dotações orçamentárias consignadas no Orçamento Geral do Distrito Federal num montante nunca inferior a $12 \%$ da respectiva Proposta Orçamentária Anual;

c) produto de operações de crédito em acôrdo espécial com o Banco da Prefeitura do Distrito Federal; Banco Nacional de Desenvolvimento Econômico; Banco do Brasil S.A.; Banco Nacional de Crédito Cooperativo; Caixas Econômicas; 
d) produto da arrecadação da Contribuição de Melhoria nos têrmos da regulamentação a ser promovida pela Prefeitura, 60 (sessenta) dias após a publicação desta lei;

e) percentagem do produto da arrecadação dos impostos de vendas e consignações, predial e territorial, nos têrmos da regulamentação, a ser promovida pela Secretaria das Finanças 60 (sessenta) dias após a publicação desta lei;

f) revisão e modernização do sistema tributário do Distrito Federal vinculando-se o produto do aumento da arrecadação à Operação Guanabara; aperfeiçoamento do mecanismo arrecadador;

g) juros das contas especiais da Operação Guanabara abertas nos estabelecimentos de crédito já mencionados, para depósito e movimentação dos recursos previstos nesta lei;

h) taxas, emolumentos, rendimentos e lucros decorrentes da execução das realizações e contratos da Operação Guanabara;

i) dotações consignadas no Orçamento Geral da União que a Bancada Carioca, nas duas Casas do Congresso Nacional conseguir para a Operação Guanabara; cota especial dos recursos da Operação Municipio (Plano Nacional), destacada para a Operação Guanabara;

j) rendas eventuais que lhe forem atribuídas; taxas especificas; vinculação de' adicionais;

Parágrafo único. A indenização a que se refere o item a não poderá ser inferior a $50 \%$ da estimativa total dos recursos vinculados à Operação Guanabara em seu primeiro qüinqüênio.

Art. 23. O Poder Executivo promoverá, desde já, entendimentos e firmará acôrdos ou convênios, com Autarquias, Sociedades de Economia Mista, Bancos, Associações Rurais, Industriais e Comerciais, Cooperativas e Emprêsas privadas, no sentido de estabelecer o esquema de financiamento misto da Operação Guanabara, fixando as condições, natureza e volume da respectiva participação.

Art. 24. Fica o Poder Executivo autorizado a contrair empréstimos destinados ao custeio e financiamento da Operação Guanabara, planos e projetos que a integram, nos têrmos, condições, volume e prazos fixados pela Lei Financeira.

Art. 25. Para garantia dos empréstimos ou com o fim de reforçar o financiamento do Plano de Obras, Empreendimentos e Serviços, fica o Poder Executivo autorizado a emitir Apólices ou Obrigações da Operação Guanabara até o montante de $\operatorname{Cr} \$ 12.500 .000 .000,00$ (doze bilhões e quinhentos milhõe's de cruzeiros) no qüinqüênio da Operação Guanabara.

Art. 26. A Secretaria de Finanças deverá tomar tôdas as providências e expedir os atos necessários à emissão especial referida no artigo anterior.

Art. 27. A Lei Financeira estabelecerá, em Regulamento Especial, o valor nominal das Obrigações da Operação Guanabara, prazos, condições de resgate, tabelas de amortização e demais minúcias técnicas da operação.

Art. 28. Fica o Poder Executivo autorizado a celebrar contratos para aquisição, inclusive no exterior, dos materiais e equipamentos indispensáveis à execução da Operação Guanabara. 


\section{Código Tributário}

Art. 29. Fica o Poder Executivo autorizado a contratar ou organizar, desde já, uma Comissão Técnica destinada a proceder à revisão do Sistema Tributário do Distrito Federal é elaboração do respectivo Código.

Parágrafo único. Fica também o Poder Executivo autorizado a organizar os projetos relativos aos instrumentos legais ou convencionais, mencionados nos arts. $5^{\circ}, 7^{\circ}$ e $8^{\circ}$.

\section{Administração}

Art. 30. Sessenta $(60)$ dias após o encerramento dos trabalhos do Departamento de Urbanismo (art. $5 .^{\circ}$, a) entrará em imediato funcionamento a Administração da Operação Guanabara.

Art. 31. Fica instituida a Administração da Operação Guanabara para coordenar e executar as obras, empreendimentos e serviços que a integram.

$\S 1^{\circ}$ O Prefeito Municipal será o Administrador -Geral da Operação Guanabara, auxiliado por sete (7) Assessôres Técnicos.

$\S 2 .^{\circ}$ A estrutura e funcionamento da Operação Guanabara, no que se refere à sua Administração,-serão estabelecidas pelo Sistema de Ratos Complementares e pelas disposições contidas no Regulamento da presente lei.

Art. 32. O Poder Executivo expedirá o Regulamento da presente lei sessenta $(60)$ dias após a sua publicação.

Art. 33. Esta lei entrará em vigor na data de sua publicação, revogadas as disposições em contrário.

\section{DOCUMENTAČ̃̃o ANEXA}

\section{I - Apuração do Censo Funcional do Estado da Guanabara}

Rio de Janeiro, 22 diz outubro de 1960 (Exposição de Motivos dirigida ao Secretátio-Geral de Administração do Estado da Guanabara, Dr. Antônio Barsante dos Santos, pelo Diretor do Serviço de Documentação do Estado e Dirigente do Grupo de Trabalho instituido pelo Embaixador SetTe CÂmara, Governador Provisório, para Apuração do Censo Funcional).

Senhor Secretário-Geral.

O Grupo de Trabalho para Apuração do Censo Funcional tem a satisfação de encaminhar a V. Ex ${ }^{a}$ os primeiros resultados decorrentes dos levantamentos estatísticos e do inquérito que vem realizando desde o início de suas atividades até a presente data.

(*) Observação: - Com a mudança da Capital Federal para o Planalto Central (Brasilia) intensificam-se, no momento, os estudos a respeito da nova Capital cuja construção se encontra em andamento acelerado. A «Operação Guanabara» equaciona e resume os problemas e aspirações do atual Distrito Federal. Qual será o destino do Rio de Janeiro com a mudança da Capital para Brasilia? A «Operação Guanabana» responde a esta pergunta e sugere as providências indispensáveis que devem ser tomadas a êsse respeito. 
São dados resumidos e condensados num Quadro Sumário destinado, exclusivamente, a proporcionar a V. Ex ${ }^{a}$ informações preliminares, antecipando o conhecimento das primeiras conclusões e resultados do Censo Funcional, à medida em que o Grupo de Trabalho encerra as suas atividades nos Setores de Recebimento, Revisão e Codificação e acelera a fase final de Perfuração, Conferência e Apuração dos formulários e demais elementos coligidos, em colaboração com o Serviço Mecanográfico.

Como é natural, são informações preliminares, sucetiveis de correção, que permitem, todavia, um conhecimento mais objetivo da situação do Estado da Guanabara no tocante à massa de servidores por intermédio dos quais se exercem as atividades administrativas estaduais. Depois de sucessivas verificações e conferências, o Grupo de Trabalho está ultimando, para a apuração mecânica posterior o "dossier" contendo os resultados e dados finais e definitivos. Desde já se pode adiantar que o Censo Funcional traduz, com fidelidade e rigorosa precisão estatística, o panorama da situação do Estado da Guanabara no que se refere a um dos seus problemas fundamentais de Govêrno e Administração, constituindo, ao mesmo tempo, um manancial precioso de informações seguras e conhecimentos positivos,, indispensáveis à formulação das melhores soluções para os referidos problemas. Os resultados do Censo Funcional, permitirão, além disso, a elaboração de uma nova Politica, no campo da Administração de Pessoal, capaz de atender aos reais interêsses e conveniências do Estado da Guanabara.

A partir de 21.7 .60 , cêrca de 100.000 (cem mil) formulários contendo - Questionário a ser preenchido, foram remetidos aos 1.353 Núcleos comporentes dos 15 Lotes em que se acham distribuídos os servidores do Estado Ao Setor de Recebimento foram devolvidos, depois de preenchidos pelos servidores, até a presente data, 76.373 formulários. A situação é, no momento, a seguinte:

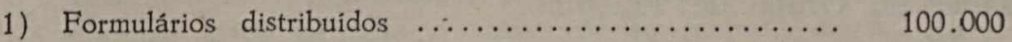

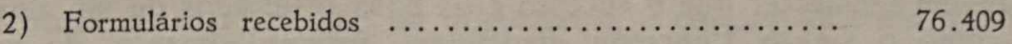

3) Formulários a receber, ainda na dependência de conferência e correções:

3.1 - Tribunal de Contas .............. 435

3.2 - Montepio do Estacio ............ 1.000

3.3 - Administração dos Estádios (ADEG) · 243

3.4 - Assembléia Legislativa do Estado ..... 780

3.5 - Banco do Estado da Guanabara .... 1.500

3.6 - Departamento de Estradas de Rodagem 4.500

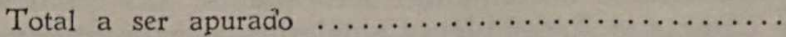

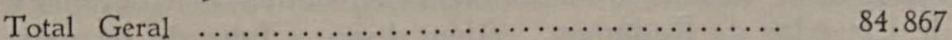

O Grupo de Trabalho para Apuração do Censo Funcional, instituido pela Portaria n. 893, de 21.7.60, vem levando a efeito ingentes esforços no sentido de realizar a missão que lhe foi atribuída e que é de inegável importância para o Estado da Guanabara. 
Cumpre acentuar, todavia, que desde o início, algumas dificuldades fertubaram o funcionamento normal do Grupo de Trabalho, reduzindo os niveis de eficiência e a rapidez das suas atividades. A fim de anular os obstáculos e fatôres adversos à execução do Censo Funcional, dentro dos prazos previstos, V. Ex promoveu, através da Portaria $n^{\circ} 1.254$, de 24 de agôsto de 1960, a reorganização do Grupo de Trabalho tendo em vista acelerar a plena e satisfatória execução do empreendimento. Com as providências autorizadas por $\mathrm{V}$. Ex $\mathrm{Ex}^{\mathrm{a}}$, nessa mesma oportunidade, tornou-se possivel intensificar o ritmo dos trabalhos em andamento e as medidas postas em prática asseguram, desde já, o êxito integral da iniciativa.

A extrema complexidade e as proporções do Censo Funcional, no recém criado Estado da Guanabara, determinaram a subdivisão do Grupo de Trabalho em 4 Setores principais:

I - Setor de Recebimento;

II - Setor de Revisão;

III - Setor de Codificação e

IV - Setor de Perfuração, Conferência e Apuração.

A experiência de funcionamento do Grupo de Trabalho demonstrou, no entanto, que deveria ter sido igualmente previsto e implantado, nessa estrutura rudimentar, desde o comêço dos trabalhos, um Setor de Relações Públicas incumbido da preparação psicológica do funcionalismo estadual, dos contactos com a imprensa, dos entendimentos com os chefes ou responsáveis pelas diversas repartições, dos esclarecimentos aos servidores e ao público - em resumo, da solução de inúmeros problemas de orientação, informações, assessoramento e coordenação. A ausência de um Setor incumbido dêsses encargos subsidiários, mas relevantes, contribuiu para sobrecarregar as dificuldades do Grupo de Trabalho.

Convém esclarecer que o sucesso e os bons resultados de um empreendimento como o Censo Funcional dependem, primordialmente, de uma boa receptividade e da mais intensa colaboração que se puder obter de todos os Órgãos e Serviços da Administração Estadual, bem como da compreensão e irrestrito apoio da massa dos servidores.

Não se criou, desde o início, o "clima" favorável à execução do Censo Funcional como um imperativo, uma necessidade impostergável e fator indispensável à solução de problemas fundamentais de Govêrno e Administração, no Estado da Guanabara. Para que se tenha uma idéia concreta das dificuldades basta considerar que sòmente agora foi possivel ultimar a distribuição dos questionários abrangendo a totalidade das repartições, inclusive o Tribunal de Contas, a Assembléia Legislativa, o Montepio e o Departamento de Estradas de Rodagem. Além disso, a falta de recursos materiais e financeiros e de pessoal especializado, retardaram o ritmo de execução do Censo Funcional.

Não obstante iniciados sem a indispensável preparação psicológica e um rigoroso planejamento técnico, os trabalhos do Censo Funcional encontram-se, nesta data, $(22.10 .60)$ pràticamente encerrados nos Setores de Recebimento, 
Revisão e Codificação podendo ser imediatamente iniciada a fase final de Perfuração, Conferência e Apuração. Se porventura o Grupo de Trabalho dispuzesse de uma Equipe Técnica inteiramente dedicada à execução do Censo Funcional em regime de tempo integral, quatro meses teriam sido suficientes; a esta altura pràticamente encerrada a operação censitária, o Serviço de Planejamento estaria ém condições de iniciar a análise, interpretação e divulgação dos elementos apurados.

Circunstâncias especiais impediram, no entanto, a adoção do regime de tÆmpo integral e dedicação exclusiva. Os responsáveis pelos Setores básicos de Recebimento, Revisão e Codificação, Perfuração, Conferência e Apuração, continuaram desempenhando suas atribuições normais na chefia de serviços de que não poderiam ser afastados sem prejuizo para a Administração.

Por outro lado, não seria aconselhável promover a substituição de uma Equipe constituída dos melhores elementos disponiveis para execução de uma tarefa aparentemente simples, mas, na realidade, sumamente especializada e de grande envergadura quanto ao seu conteúdo técnico, dimensões e finalidades.

Acresce salientar o fato de se encontrar a Secretaria-Geral de Administração inteiramente mobilizada e engajada na solução de múltiplos e urgentes problemas, aos quais teria de ser forçosamente atribuida a mais alta prioridade como decorrência das profundas modificações estruturais que o Estado da Guanabara atravessa nesta fase de sua evolução histórica.

Merecem destaque, no âmbito da Secretaria-Geral de Administração, es problemas relativos à elaboração do Plano de Classificação de Cargos do Serviço Civil do Poder Executivo do Estado, os projetos de reorganização administrativa, a implantação de reformas inadiáveis e tôda uma série de iniciativas e providências que seria longo enumerar. Ainda no conjunto das mencionadas circunstâncias, - cujos reflexos não seria lícito obscurecer ou ignorar, é fácil avaliar o significado, a intensidade e as conseqüências da mudança da Capital para Brasília e conseqüente transformação do antigo Distrito Federal no atual Estado da Guanabara, o caráter de transitoriedade do Govêrno Provisório e sua duração naturalmente limitada, a exigüidade do tempo disponivel para o ataque simultâneo a uma imensa variedade de problemas e assuntos, na órbita de cada Secretaria, o impacto emocional da sucessão presidencial e das eleições estaduais e assim sucessivamente.

Quanto aos colaboradores incumbidos da execução material das tarefas, foram os me'smos escolhidos dentre servidores da Secretaria-Geral de Administração, e distribuidos pelos 4 Setores componentes do Grupo de Trabalho de acôrdo com a respectiva especialização profissional.

A Portaria n. ${ }^{\circ} 893$, de 21.7.60, traçou, em seus delineamentos gerais, as seguintes atribuições especificas dos colaboradores então relacionados:

I - No Setor de Recebimento:

a) recebimento dos formulários devidamente preenchidos pelos servidores do Estado da Guanabara;

b) verificação dos formulários segundo a repartição de origem tendo em vista o seu colecionamento correto; 
c) providenciar, junto ao Departamento do Pessoal para a redistribuição e novo preenchimento dos formulários impugnados ou devolvidos;

d) encaminhamento à codificação do material devidamente revisado III - No Setor de Codificação: formulário;

a) reexame e codificação, em números, dos dados constantes de cada

b) ajustamento dos casos omissos aos critérios gerais de codificação єstabelecidos;

c) entrosamento com o Setor de Revisão para fins de novo preenchimento ou retificação das declarações impróprias;

d) preparo e remessa dos formulários, completamente codificados.

IV - No Setor de Perfuração, Conferência e Apuração:

a) execução dos trabalhos de perfuração e conferência dos formulários to Censo Funcional, anteriormente codificados;

b) apuração dos elementos coligidos de acôrdo com o plano geral pstabelecido.

V - Finalmente, o Serviço de Planejamento à vista dos levantamentos: efetuados e com os elementos obtidos efetuará a análise, critica, interpretação e divulgação dos dados apurados.

Concduído, destarte, o Censo Funiconal, a Secretaria-Geral de Adminisfração promoverá a sua destinação mais adequada e imediato aproveitamento, utilizando-o conforme julgar mais oportuno e conveniente aos interêsses do Estado da Guanabara.

A exemplo do que ocorreu com a Equipe dos responsáveis pela chefia e assessoramento do Grupo de Trabalho, também o pessoal a ela subordirado, - incumbido da execução das várias atribuições do Censo Funcional, não foi convenientemente mobilizado para êsse fim, em regime de tempo ix.tegral. Além das enormes dificuldades no tocante à localização, obtenção e conservação de pessoal profissionalmente qualificado, os colaboradores finalmente reunidos no Grupo de Trabalho não foram desligados das suas funções habituais nas repartições de origem, durante as horas de expediente diário.

Apesar da boa vontade e comprovada dedicação dêsses servidores, seria impossivel realizar um empreendimento como o Censo Funcional, - dentro dos prazos preestabelecidos, enquanto os referidos servidores permanecessem inteiramente dedicados às suas funções de rotina durante' todo o expediente normal das respectivas repartiçóes trabalhando fora das horas do expediente, pela manhã ou à noite, sem receber até agora, qualquer espécie de gratifiração adicional, - em virtude da falta de recursos financeiros, - o fato é que êsses servidores vêm prestando uma colaboração excepcional, dentro das limitações e problemas de tôda a ordem que o Grupo de Trabalho vem enfrentando no desempenho de sua missão.

Mas, as recentes decisões de V. Ex ${ }^{a}$. - autorizando o trabalho dos coiaboradores durante o expediente normal das repartições em que estão 
lotados e, sobretudo, determinando o aproveitamento integral do Serviço de Planejamento na ultimação do Censo Funcional - já começaram a surtir os efeitos previstos. Como resultado das providências tomadas foi intensificado o ritmo dos trabalhos em todos os setores. É de se prever, em face do andamento acelerado dos serviços, o encerramento definitivo do Censo Funcional, dentro de um prazo razoável de 30 dias. As operações básicas do empreendimento iniciado a 21.7 .60 se encontram em pleno desenvolvimento, com alguns Setores já na fase final de encerramento das respectivas atividades. Pràticamente ultimados os trabalhos de distribuição, recebimento, revisão e codificação, cabe, agora, ao Setor de Perfuração, Conferência e Apuração - em articulação com o Serviço Mecanográfico - executar os encargos finais de perfuração e conferência dos formulários do Censo Funcional, bem como da apuração mecânica dos elementos coligidos.

A experiência do Censo Funcional está demonstrando a situação de sbsoluta precariedade em que se encontra o Estado da Guanabara no tocante à obtenção de estatísticas administrativas. Não existem setores ou órgãos específicos incumbidos de efetuar os levantamentos estatísticos indispensáveis, dispondo de equipamento humano, técnico e material adequado à boa execução dêsses encargos. Quaisquer informações ou dados estatísticos fidedignos têm de ser elaborados e obtidos em repartições completamente desaparelhadas e desarticuladas entre si, espalhadas nas diversas Secretarias de Estado notadamente, na Secretaria-Geral de Administração e nas Secretarias-Gerais de Finanças e do Interior. Entretanto, é da maior importância para o Estado a urgente correção dessa anomalia.

$\mathrm{Na}$ situação atual, a coleta, sistematização, crítica e interpretação dos dados e fatos numéricos pertinentes a pessoal, material, orçamento, obras, organização e documentação apresentam dificuldades quase insuperáveis e, -_ o que é pior - os dados obtidos são freqüentemente desatualizados e passiveis de correção, exigindo uma permanente verificação.

Essa carência de dados rigorosamente exatos, em virtude da ausência de boas estatísticas administrativas, não permitiu, até agora, obter-se um conhecimento objetivo, concludente e integral dos contingentes humanos a serviço do Estado da Guanabara: - número exato dos efetivos de servidores, catejorias, distribuição, traços característicos, volume das despesạs e demais ocorrências básicas. Impõe-se, por conseguinte, a execução de um programa mínimo de aperfeiçoamento das estatísticas administrativas a fim de que o Govêrno Estadual disponha de informações seguras e positivas. Os resultados, os ensinamentos e a experiência do Censo Funcional constituem um excelente ponto de partida, proporcionando, ao mesmo tempo, diretrizes, bases e contribuições positivas à formulação da politica mais conveniente aos interêsses do Estado no âmbito da administração de pessoal, da situação e andamento dos serviços públicos, em geral.

O Censo Funcional é uma radiografia impressionante cuja análise, além de revelar o panorama do Estado no tocante à situação do funcionalismo constitue um poderoso instrumento a serviço da Administração.

Apesar de instituído oficialmente a 21-7-60, a execução prática do Censo Funcional começou com a posterior distribuição aos servidores do 
Estado da Guanabara de um Questionário que, embora cuidadosamente planejado, revelou, idesde logo, uma complexidade excessiva, contribuindo para retardar o andamento da operação censitária e dificultar a apuração final dos resultados coligidos.

A impressão dos formulários foi, além disso, quantitativamente insuficiente, de tal forma que, órgãos como o Departamento de Estradas de Rodagem e algumas repartições isoladas, sòmente nesta primeira quinzena de outubro puderam receber os mencionados formulários.

A excessiva demora e insuficiente distribuição dos formulários a serem individualmente preenchidos pela totalidade dos aludidos servidores, espalhados no Estado da Guanabara, contribuiram para retardar o andamento geral dos trabalhos e tumultuar a execução do Censo Funcional, em tôdas as suas fases. Quase dois meses foram consumidores em atividades priliminares e subsidiárias que, a rigor, deveriam ser por assim dizer automáticas.

Por outro lado, grande massa de servidores manifestou-se apática, desconfiada e apreensiva, demonstrando completa ignorância e desinterêsse com relação à iniciativa, attribuindo ao Censo Funcional intuitos punitivos ou secretos. Semelhante estado de espirito, agravado pela falta de preparação psicológica e inteiro desconhécimento dos verdadeiros objetivos do Censo Funcional, é sintomático das dificuldades que o Grupo de Trabalho teria de enfrentar. Criou-se, mesmo, uma situação constrangedora, a ponto de ser necessário adotar, em fins de setembro, a medida drástica consubstanciada na retenção dos cheques de pagamento dos retardatários que, por um motivo qualquer, deixaram de preencher os formulários expedidos, ou fizeram-no fora dos prazos estipulados.

Contudo, o obstáculo máximo e fator primordial de pertubação e retardamento do Censo Funcional, se encontra obviamente, na quantidade impressionante dos formulários mal preenchidos, incompletos ou omissos. Os Setores de Recebimento, Revisão e Codificação tiveram, por êste motivo, sèriamente comprometidos os respectivos calendários ide encargos, impossibilitados de concluirem os trabalhos dentro dos prazos prefixados.

Os meses de agôsto e setembro foram inteiramente consumidos no trabalho exaustivo de impugnação ou devolução de formulários omissos e incompletos, sucessivas correções e retificações de formulários mal preenchidos ou inexatos e assim sucessivamente.

A conseqüência imediata dêsse ponto de estrangulamento foi a completa paralização do Setor de Perfuração, Conferência e Apuração até o presente momento. Efetivamente seria anti-econômico, contraproducente e desnecessário, encaminhar formulários nestas condições e em quantidade reduzida, ao referido Setor, para os trabalhos de perfuração, conferência e Apuração até o presente momento. Entretanto, até o fim do corrente mês de outubro, deverá o Setor de Perfuração, Conferência e Apuração receber, em sua quase totalidade, os volumes contendo os formulários devidamente codificados, num montante calculado em cêrca de 70.000 unidades - ou seja, quase $80 \%$ do total - e o restante, no decorrer da primeira se'mana de novembro vindouro. Felizmente, o Serviço Mecanográfico em face da tradicional eficiência técnica de seu pessoal, está preparado para executar os trabalhos 
com a maior brevidade possivel. Uma ofensiva final de restabelecimento dos prazos prefixados e respectivo énquadramento do Censo Funcional na hipótese em que seja mobilizado o parque das máquinas disponiveis nas diversas Secretarias de Estado, - poderia ser levada a efeito, reforçando-se e ampliando-se, destarte, a capacidade atual do Serviço Mecanográfico. firal de restabelecimento dos prazos prefixados e respectivo enquadramento do Censo Funcional - na hipótese em que seja mobilizado o parque das máquinas disponíveis nas diversas Secretarias de Estado, - poderia ser levada a efeito, reforçando-se e ampliando-se, destarte, a capacidade atual do Serviço Mecanográfico.

Algumas observações se impõem com relação ao Questionário elaborado - ponto de partida e base do Censo Funcional, através dos formulários distribuídos. Planejado com a finalidade de proporcionar a maior soma possivel de informações concretas e dados numéricos, possibilitando identificar e caracterizar a situação exata de cada servidor, o Questionário abrange 12 grupos ou itens de problemas pessoais e funcionais. As informações requeridas dos servidores compreendem de início: nome, matrícula, sexo, idade, nacionalidade, residência, família. Em seguida, o Questionário formula as indagações preponderantemente funcionais, dentre as quais se destacam: cargo ou função, classe, padrão, símbolo ou referência, natureza (isolado, em comissão, efetivo, ou de carreira), quadro (permanente, suplementar, suplementar especial, suplementar especial da City extra); funcionário, extranumerário contratado, tabela de mensalista, tabela suplementar; localização e lotação (Secretaria a que pertence, repartição em que está lotąo ou em exercício); requisitados (casos e minúcias da situação); ingresso (por concurso ou prova pública, prova interna, livre nomeação ou admissão); regimem de trabalho, (periodo de horas de atividade e de descanço); exercício cumulativo de outros cargos, funções, emprêgo ou atividade - tanto no serviço público federal, estadual ou municipal, como em emprêsas particulares - discriminação; instrução (discriminação completa, inclusive indicação dos cursos de aperfeiçoamento ou avulsos, do servidor); enumeração dos cargos ou funções públicas já exercidos; tempo de serviço (municipal, federal e estadual); retribuição mensal (vencimento ou salário base, gratificação adicional, outras gratificações, percentagens ou participações, salário-família, qüinqüênios, outras retribuições) etc.

As incorreções, deficiências e atrasos verificados no preenchimento dos formulários, resultaram, possivelmente, da complexidade do Questionário, aliada à resistência passiva, desconfiança, baixo nivel cultural e injustificado temor de grande número de servidores, apreensivos quanto à probabilidade de utilização do Censo Funcional como instrumento disciplinar ou punitivo. Dai a imprecisão das respostas, a relutância no preenchimento dos formulários e demais deficiências cujos reflexos atuaram negativamente em detrimento da rapidez e eficiência do Grupo de Trabalho.

O Questionário, tal como planejado, aumentou as proporções do Censo Funcional, ocasionando, paradoxalmente, problemas técnicos adicionais no que se refere à codificação numérica e apuração mecânica de uma enorme variedade de dados e informações de natureza evidentemente complexa e difícil redução sintética pelo Serviço Mecanográfico. 
A situação anterior ao Censo Funcional pode ser resumida no seguinte Quadro, de acôrdo com os dados fornecidos pelo Serviço de Pagamento:

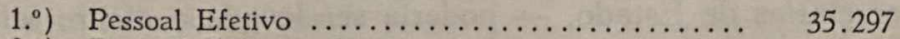

2.0) Pessoal Extranumerário ................. 40.143

3. ) Pessoal em Comissão ................... 693

76.133

O Pessoal Efetivo se encontrava distribuído da seguinte forma:

a) Quadro Permanente, 27.145 cargos;

b) Quadro Suplementar, 7.131 cargos;

c) Quadro Suplementar Especial, 477 cargos;

d) Quadro Suplementar Especial da City, 13 cargos;

e) Quadro Extra, 551 cargos - ou seja, um total de 35.297.

O Quadro Permanente compreendia:

a) 2.223 cargos isolados;

b) 14.637, Cargos de Carreira;

c) Magistério 9.781;

d) Teatro Municipal, 368;

e) Serviço de Teatro, 122. - Total: 27.145.

O Quadro Suplementar abrangia:

a) cargos isolados, 605;

b). Cargos isolajdos com Qüingüênios, 3.012;

c) Cargos de Carreira, 2.718;

d) Magistério, 226;

e) Cargos Provenientes de Ações Judiciais, 570. - Total: 7.131.

O Quadro Suplementar Especial apresentava:

a) Diversos, 428;

b) Magistério, 49. - Total: 477. Finalmente, o Quadro Especial da City e o Quadro Extra, compreendiam, respectivamente, cargos em número de 13 a 531 .

Quanto aos 40.143 Extranumerários, era a seguinte a distribuição dêsse pessoal:

a) Gabinete do Governador, 164;

b) Rádio Roquete Pinto, 109;

c) Conselho de Recursos Fiscais, 4;

d) Procuradora-Geral, 81;

e) Secretaria-Geral de Administração, 1.820;

f) Secretaria-Geral de Agricultura, 2.174;

g) Secretaria-Geral de Educação, 5.691;

h) Secretaria-Geral de Finanças, 771;

i) Secretaria-Geral do Interior, 1.738;

j) Secretaria-Geral de Saúde, 7.646;

k) Secretaria-Geral de Viação, 18.391; 
l) Superintendência de Transportes, 1.298;

m) Teatro Municipal, 265. - Total Geral do pessoal extranúmerário: 40.143 .

Finalmente, os 683 Cargos em Comissão - inclusive 1 Governador, 7 Secretários-Gerais e 1 Procurador-Geral estavam assim distribuidos:

a) Gabinete do Governador, 3;

b) Secretaria-Geral de Administração, 31;

c) Secretaria de Agricultura, 35;

d) Secretaria de Educação, 121;

e) Secretaria de Finanças, 59;

f) Secretaria de Interior, 47;

g) Secretaria de Saúde, 170;

h) Secretaria de Viação, 164;

i) Superintendência dos Transportes, 12;

j) Procuradoria-Geral, 1;

k) Sursan, 31. - Total Geral do Pessoal em Comissão: 683.

Enquanto se recolhem, em sua totalidade, os formulários distribuidos, e se prepara a apuração mecânica dos elementos coligidos, resolveu o Grupo de Trabalho efetuar uma pesquisa de amostragem, selecionando alguns itens básicos dos Questionários já preenchidos por 76.373 servidores, tais como:

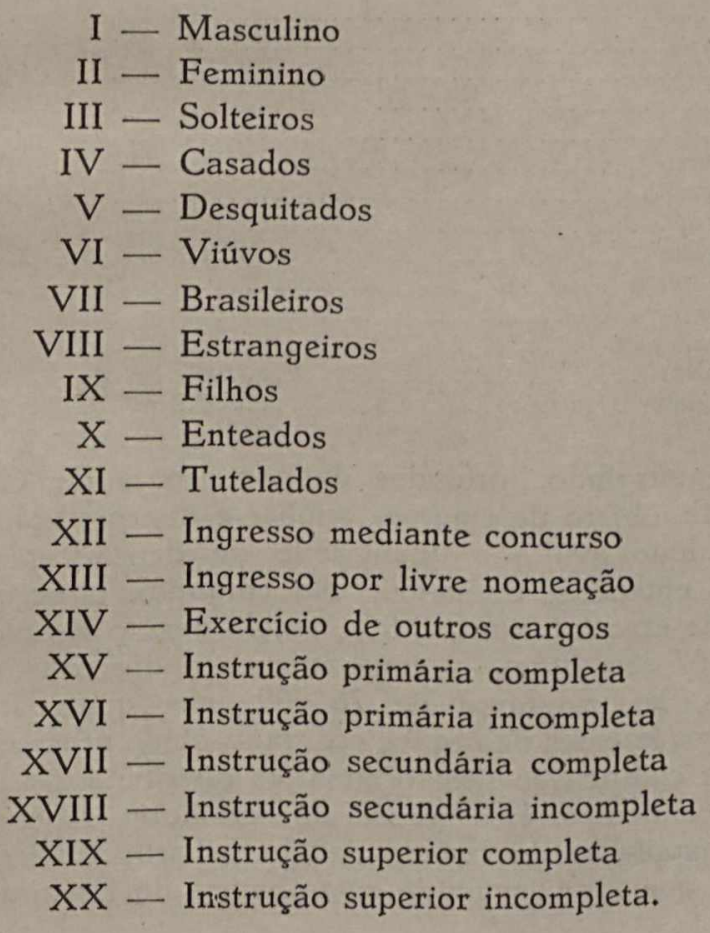


Tais itens correspondem aos seguintes atributos de personalidade:

a) sexo;

b) estado civil;

c) nacionalidade;

d) encargos de familia;

e) forma de ingresso no cargo ou função;

f) exercício de outros cargos;

g) nivel de instrução.

Sem entrar em análises minuciosas, releva notar de logo, uma observação interessante. Cargos de remuneração elevada são ocupados por servidores cujo nivel de instrução é o primário, enquanto funções muito subalternas são exercidas por portadores de diploma de nivel universitário. Todavia, essa análise em profundidade dos resultados do Censo deve servir aos objetivos do futuro Serviço de Classificação de Cargos, previsto no Plano de Classificação de Cargos.

São os seguintes os dados correspondentes à mencionada pesquisa de amostragem quanto aos itens acima selecionados:

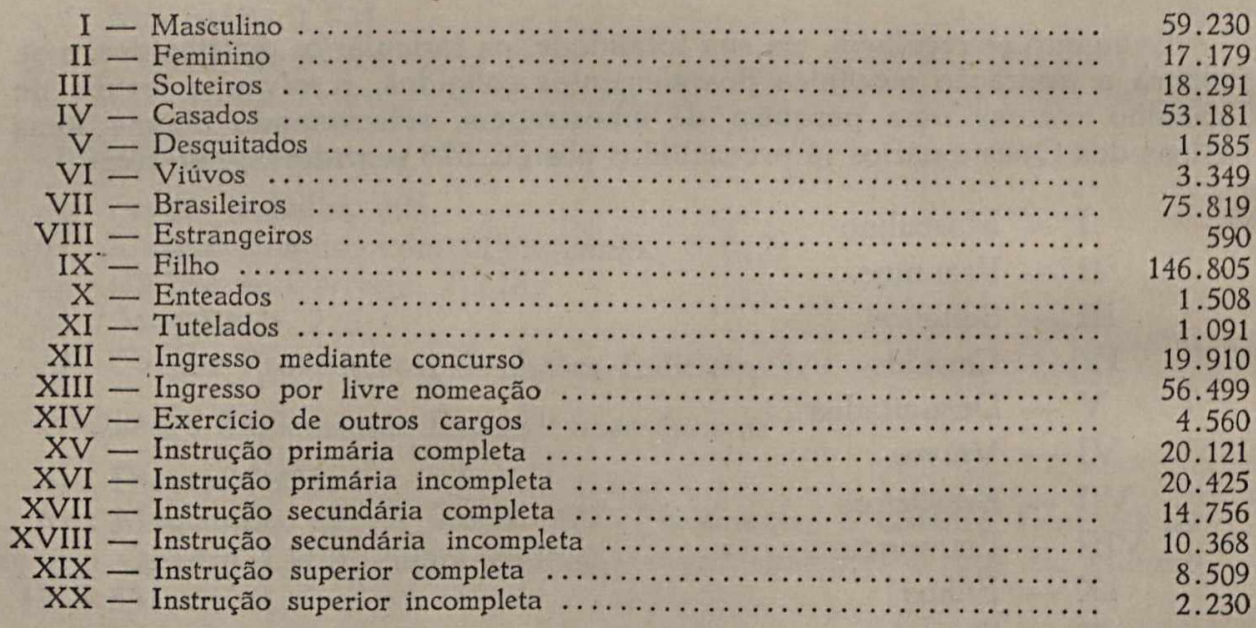

Os números que estão surgindo, oriundos das apurações do Censo Funcional, serão, naturalmente, objeto de rigorosa análise e interpretação, no momento oportuno. Desde logo avulta a quantidade de dependentes quase 150.000, entre filhos, enteados, tutelados. No conjunto, a pesquisa efetuada, com uma margem de êrro inferior a $0,3 \%$, revela para o Estado da Guanabara um total de 84.867 servidores - consoante os dados constantes dos formulários preenchidos, no montante de 76.409 , aos quais foram adicionaidos cêrca de 8.458 provenientes de órgãos nos quais ainda prosseguem os trabalhos de recebimento e codificação dos formulários distribuídos. Com as respectivas familias e dependentes, essa massa de servidores representa uma parcela ponderável da população do Estado da Guanabara. O Serviço Mecanográfico, à medida em que fôr concluindo os trabalhos de Perfuração, 
Conferência e Apuração, entregará a V. Exa. os mapas, gráficos e boletins contendo os resultados finais e dados definitivos do Censo Funcional.

Aproveito a oportunidade para reiterar a V. Exa. as expressões do mais alto aprêço e distinta consideração.

Grupo de Trabalho para apuração do Censo Funcional. - Araújo Cavalcanti. - Wladimiro Bogd Anoff. - Oscar Noronha Filho. - Byron Tôrres de Freitas. - Alberto Souza Dunningham.

II - Situação financeira e orçamentária do Estado da Guanabara Discurso do Deputado Federal Océlio de Medeiros, na Câmara Federal, em Brasilia (julho de 1960).

O Sr. OcÉlio DE Medeiros: (Lê a seguinte comunicação) - Senhor Presidente,Realiza-se, hoje, no Estado da Guanabara, a Convenção do Diretório Regional do meu partido, para homologar a candidatura do nosso eminente colega Marechal Ångelo Mendes de Morais ao govêrno do seu Estaido Natal.

Ao assinalar tão auspicioso evento, que constitui motivo de satisfação para todos aquêles que acompanharam, de perto, a grandiosa obra administrativa do ex-prefeito do Distrito Federal, encareço a atenção da Casa para a aflitiva situação financeira da nova Unidade Federativa, acentuando a responsabilidade do ilustre candidato do P.S.D. para equacioná-la e resolvê-la, com a sua reconheci,da probidade, experiência administrativa e incomparável dedicação aos superiores interêsses do País.

Com efeito, Sr. Presidente e Srs. Deputados, as condições financeiras do Estado da Guanabara se apresentam sumamente dificeis, nas atuais circunstâncias, em que essa Unidade da Federação tem de enfrentar, além dos seus tradicionais problemas, o impacto das repercussões decorrentes da transferência ja Capital Federal para o Planalto Central do País.

A situação que o Estado atravessa se agravou consideràvelmente nos últimos meses, de tal forma que o Embaixador Sette Câmara, Governador do ex-Distrito Federal, determinou por em execução um Plano de Economia da ordem de dez bilhões de cruzeiros. Neste sentido expediu instruções aos Secretários-Gerais do Estado, seus auxiliares imediatos, para que promovam, com urgência, os cortes que se fizerem necessários, no âmbito das respectivas Secretarias, tendo em vista comprimir as despesas a fim de que o Estado da Guanabara possa atender aos seus compromissos mais urgentes, tais como os pagamentos do pessoal e do resto a pagar.

O Plano de Compressão de Despesas, no montante de dez bilhões, é uma demonstração concreta da precariedade financeira e orçamentária do novo Estado, cujas perspectivas se antecipam ameaçadoras, compelindo o Govêrno a medidas drásticas, de conseqüências nefastas e imprevisiveis para a tranqüilidade e bem-estar da população da grande metrópole que desde os tempos anteriores à Independência, funcionou como sede do Govêrno do País, até 21 de abril de 1960, desempenhando uma função de transcendental importância na formação da nacionalidade e no desenvolvimento da civilização brasileira. Essas perspectivas são particularmente graves no tocante à paralização de obras, serviços e empreendimentos inadiáveis em uma cidade 
como o Rio de Janeiro que ainda é o pôrto mais importante do País e um dos principais núcleos de cultura e centros de atração turística do continente, além de constituir uma concentração de aglomerados industriais indispensáveis à própria sobrevivência da Federação. A paralização das obras públicas iniciadas - diretamente a cargo da então Prefeitura do Distrito Federal ou atribuídas à SURSAN - teria a significação de um colapso para a laboriosa população carioca - cêrca de três milhões e quinhentos mil brasileiros - que atravessam, no momento, sérias dificuldades no tocante aos problemas de abastecimento e preços de gêneros alimentícios, água, energia, tráfego, habitações populares e tantos outros, típicos de uma cidade incostestàvelmente situada entre as maiores aglomerações demográficas e urbanas do Mundo. Por outro lado, convém relembrar a conjuntura especial decorrente da transferência da Capital para Brasília, em virtude de preceito constitucional, ingressando o antigo Distrito Federal em uma fase de transição que apresenta os mais complexos problemas estruturais de ordem política, administrativa, econômica, financeira e social, destacando-se, no conjunto dêsses variados problemas, a sua transformação no Estado da Guanabara. A interiorização da Capital Federal, como não podia deixar de acontecer, está provocando profundas modificações, cujo maior impacto atinge, precisamente, o nôvo Estado da Guanabara.

Estas são as razões de ser da patriótica iniciativa do Presidente Juscelino Kubitschek ao submeter à alta deliberação do Congresso Nacional a Mensagem $n^{\circ}$ 123-A-60, encaminhando o Projeto de Lei que autoriza o Poder Executivo a prestar contribuição financeira da União, até o montante de três bilhões de cruzeiros, destinados à conclusão das obras públicas iniciadas na Cidade do Rio de Janeiro. (Projeto $\mathrm{n}^{0}$ 1.846-60).

$\mathrm{O}$ Projeto destina-se a atenider à situação criada para o Estado da Guanabara com a mudança da Capital para Brasília, proporcionando ao Govêrno da Nova Unidade da Federação a necessária e inadiável assistência da União, mediante uma contribuição financeira destinada à conclusão de obras já iniciadas, que não podem e não devem sofrer solução de continuidaide, porque se configuram como do mais alto interêsse nacional pelos motivos acima expostos. Objeto de rigoroso exame nas Comissões técnicas da Câmara, encontra-se o referido Projeto em andamento, recebendo modificações e aperfeiçoamentos que o tornarão mais fàcilmente exeqüivel. Assim é que os eminentes Deputados Hamilton Prado, Martins Rodrigues e Colombo de Souza estão envidando esforços que tornarão, dentro em breve uma realidade concreta a colaboração do Poder Executivo Federal com a Administração do Estado da Guanabara no instante preciso em que mais urgente se torna a contribuição financeira proposta nos têrmos da Mensagem Presidencial.

$\mathrm{Na}$ oportunidade em que o Congresso Nacional examina, com o carinhoso aprêço que merecem, os interêsses e' problemas do povo carioca e do Estado da Guanabara, cumpre-me colaborar no limite das minhas possibilidades para acelerar o andamento do mencionado Projeto e sua rápida tramitação na esfera do Poder Le'gislativo. Faço o com satisfação, como um representante do povo que, durante longos anos, estudou, trabalhou e viveu no Rio de Janeiro, cidade à qual se encontra indissolùvelmente vinculado pelas relações de amizade, pelo afeto e pelo muito que lhe devo. Parece-me que a melhor maneira de servir a êsse objetivo é transmitir à Casa informações 
exatas e positivas a respeito da situação em que efetivamente, se encontra - Estado da Guanabara, delineando o panorama orçamentário e financeiro que justifica a concessão, em regime de urgência, de auxílio proposto de $\mathrm{Cr} \$ 3.000 .000 .000,00$, com os quais poderá o Govêrno da nova Unidade Federativa enfrentar as dificuldades que entravam o seu desenvolvimento e criam obstáculos de tôda ordem à sua Administração, como, por exemplo, a grave ameaça de paralização dos melhoramentos urbanos iniciados, suspensão do vasto programa de obras indispensáveis ao confôrto, à segurnnça, à saúde e ao bem-estar do nobre povo carioca.

I - Orçamento. A receita orçamentária, ou seja aquela presvista na Lei de Meios para o corrente execício, foi estimada em $\mathrm{Cr} \$ \ldots . \ldots \ldots \ldots$. 28.233.450.000,00. Todavia, o comportamento da arrecadação no período de janeiro a maio do corrente demonstra que a receita foi superestimada. Nesse mesmo período ela produziu, apenas, $\operatorname{Cr} \$ 8.086 .673 .031,30$, isto é, menos de $30 \%$, o que vem confirmar previsão exageradamente otimista. Para uma Receita orçada em Cr\$ 28.233.450.000,00 à Despesa, inicialmente calculada na lei orçamentária em $\operatorname{Cr} \$ 33.597 .536,00$, foi adicionada a parcela de $\operatorname{Cr} \$ 718.119 .435,50$ correspondente a créditos adicionais abertos em exercicios anteriores, com vigência no ano de 1960 . O total das autorizações de despesas atingiu, portanto, $\operatorname{Cr} \$$ 34.315.735.000,00, iniciando-se destarte, o exercício financeiro com um «deficit» de previsão de $\mathrm{Cr} \$$ 6.082.305.000,00. Considerando-se que a realização da Receita prevista, de acôrdo com os dados revelados pelo comportamento da arrecadação no período je janeiro a maio do corrente, deverá cifrar-se em tôrno de uma Receita efetiva de Cr\$23.324.950.000,00, o «deficit» previsto de inicio, deverá ser acrescido, após a correção da Receita orçada, em mais . . . . . . . . Cr\$ 4.903.500.000,00, originando-se, por conseguinte, um «deficit» real da ordem de Cr\$10.990.805.000,00, motivo da elaboração de um rígido Plano de Compressão de Despesas, o que, de fato acaba de acontecer com os cortes de $\operatorname{Cr} \$ 10.000 .000 .000,00$ determinados pelo Governador do Estado da Guanabara.

II - Arrecadação. Conforme já foi dito, até 31 de maio do corrente a Receita somou, apenas Cr\$ 8.086.673.061,30. Espera -se, com as providências tomadas pelas Secretarias-Gerais de Finanças e de Administração arrecadar, de $1^{\circ}$ de junho a 31 de dezembro, cerca de $\operatorname{Cr} \$ 15.238 .276 .938,70$. Há portanto, manifesta insuficiência de recursos em Caixa para atender ao pagamento em dia de todos os fornecedores do Estado, quer de serviços, quer de material.

III - Despesa. Até 31 de maio de 1960, a Despesa Empenhada totalizou, aproximadamente, a importância de $\operatorname{Cr} \$ 8.406 .000 .000,00$, já incluida a parte correspondente a pessoal, do mês de maio. Dêsse total até a mesma data, haviam sido pagos $\operatorname{Cr} \$ 6.180 .284 .000,00$, restando por pagar, Cr\$ 2.225.838.000,00, dos quais Cr\$ $1.100 .000 .000,00$ de pessoal e $\mathrm{Cr} \$ 1.125 .838 .000,00$ de material e despesas diversas.

IV - Compromissos de anos anteriores. Cumpre acentuar que, além do pagamento da despesa própria do exercício, foram liquidadas nos últimos 
cinco meses decorridos - obrigações provenientes dos anos anteriores no valor de cerca de $\operatorname{Cr} \$ 2.600 .000 .000,00$, sendo:

a) contas de fornecimentos de materiais e serviços $\operatorname{Cr} \$ 1.100 .000 .000,00$, e b) contas de vencimentos de dezembro e abono a servidores, .......... $\mathrm{Cr} \$ 1.500 .000 .000,00$. Convém relembrar, ainda, que os primeiros cinco meses do exercício representam um período na execução orçamentária, que não sofreu os impactos das vultosas importâncias relativas ao pagamento de amortizações de empréstimos contratuais e respectivos juros, vencendo-se as primeiras prestações do exercício no transcurso do mês de junho.

São estas, Sr. Presidente, as condições reais do Estado da Guanabara, no momento em que o Marechal Mendes de Morais, mais uma vez, terá a oportunidade histórica de administrá-lo com aquêle dinamismo, integridade e extraordinária capacidade que a Nação conhece.

Em outro ensejo, ocuparei a tribuna para analizar, em profundidade, os problemas do Govêrno e Administração do Estado da Guanabara. (Muito bem).

Diário do Congresso Nacionäl (Seção I) 14 de julho de 1960, págs. 4.738/4.739.

\section{III - Memorial de um candidato a Assembléia Constituinte do Estado da Guanabara}

No dia 3 de outubro de 1960 os eleitores do Rio de Janeiro escolherão 30 cidadãös para o fim principal de elaborarem a organização politica, jurídica e administrativa do mais novo Estado da federação.

Certamente ninguém pensa que sejam necessários sábios para essa tarefa: entretanto, devem ser eleitas pessoas equilibradas, experientes dos problemas desta cidade, dispostas ao trabalho e ao estudo, corajosas na deliberação de atitudes, e honestas.

O que falta ao Rio de Janeiro, agora Estado da Guanabara, é tudo: faltam-lhe escolas, desde as primárias às de formação profissional; é absoluta a carência de transportes, em todos os bairros e a tôdas as horas; crescem as favelas, faltam habitações populares, e só se toma conhecimento dos favelados para a demagogia eleitoral; é deficiente o suprimento đde água e precária a sua distribuição; a rêde de esgotos ainda é privilégio de poucas regiões urbanas; o lixo é problema, desde a coleta até a descarga, e não se cuidou de resolver o problema singelo de seu lucrativo aproveitamento industrial; os serviços de telefone e de gás estão em atraso, na relação com o aumento das residências e da população; o abastecimento alimentar é deficiente e o povo vive, periơdicamente, o drama da exploração dos preços nas entre-safras, por ausência de estocagem, de frigoríficos, de armazenamento, de financiamento. - Afinal, falta ao Rio de Janeiro, a mais elementar organização administrativa, sendo nós governados por um sistema burocrático onde sobram privilegiados que não trabalham e onde os verdadeiros servidores se esgotam no serviço em troca de paga irrisória: não existe, na administração do pessoal, o regime do mérito; impera, porém, o favoritismo político mais torpe e encarecedor das verbas de pessoal. 
Não se faz necessário ser estatístico ou financista ou economista para se saber que atingimos, na Guanabara, a saturação tributária, e que as indústrias e o alto comércio fogem para outros Estados, enquanto a receita do Rio de Janeiro - aquela que se exprime em valor aquisitivo, não em valor infiacionado da moeda, - vem caindo desde 1950.

Não é preciso ser estadista para compreender que os problemas financeiros do Estado da Guanabara serão ainda maiores que os da antiga Prefeitura, quando as Polícias (Civil e Militar), os Bombeiros, a Justiça local, a iluminação pública, o sistema penitenciário etc., passam do Govêrno Federal para os ombros do contribuinte carioca. - Só a manutenção dêsses antigos serviços federais de aplicação local custará à Guanabara, em 1960 (após 21 de abril), mais de um e meio bilhões de cruzeiros, à parte, naturalmente, os ordenados que estão na despesa do Govêrno Central.

Sabendo-se que o preço da administração de uma grande cidade cresce, sempre, em ritmo mais acelerado do que seu aumento populacional, e sabendo-se, ainda, que nós somos, dentre as cidades de mais de um milhão de habitantes, a que tem o mais ingrato sítio para a localização urbana, - o Rio foi classificado, por um grande jornalista francês, Raymond Cartier, como «cidade tècnicamente impossível», - é fácil compreender a magnitude das tarefas a cargo da Constituinte: o Rio de Janeiro atinge ràpidamente o limite de jensidade demográfica e, mesmo que se faça a redistribuição de seus habitantes por áreas ainda quase baldias, é tal o excedente de cetras zonas, onde existem até 4.000 pessoas por hectare, em lugar do máximo ideal de 600 , que o Estado da Guanabara só pode ter sobrevivência efetiva se aumentarmos consideràvelmente a produtividade de seus habitantes e a rentabilidade de suas atividades econômicas. Sabido que em todos os maiores centros urbanos do mundo, em Paris como em New York, em Buenos Aires como em Tóquio, a indústria de avultado porte troca a grande cidade pelas zonas de aglomeração humana menos densa, em busca de mais terra, mais água, mais energia, maiores facilidades de transporte e habitação de seus operários, o Rio não pode ter a veleidade de disputar a localização ide complexos industriais com - Vale do Paraiba, o Quadrilátero Ferrifero de Minas, ou as regiões do interior de São Paulo.

O que se impõe, afinal, para ao menos reduzir a imensidade dos problemas econômicos e financeiros do Rio de Janeiro, e o drama social do enorme proletariado carioca, é austeridade e dinâmica no seu Govêrno. Os velhos e utópicos planos urbanísticos, dos quais resultaram decretos de desapropriação de extensas áreas, com o agravamento das dificuldades com que lutam dezenas de milhares de proprietários aos quais o Govêrno não paga as desapropriações nem deixa melhor aproveitar seus bens, têm que ser substituídos por planos viáveis e sensatos, em suma exeqüiveis. - Exeqüíveis devem ser - todos os esquemas da reforma que para a Guanabara se faz mister.

No que tange à organização politica do Estado, que a Constituinte vai delinear, medite-se em como será, ela, também, problemática: a criação de município ou municipios (não poderá haver, em nosso regime federal, Estado sem Municipio) começa por ser dificultosa na delimitação de áreas, na discriminação de seus serviços públicos, e na formação de seus quadros de 
funcionários. Por outro lado, cêrca de $35 \%$ da receita da antiga Prefitura do Distrito Federal é de natureza municipal, o que reduzira a arrecadação do Estado da Guanabara e acarretará a divisão do atual corpo de funcionários vindos da Prefeitura em servidores que ficarão com o Estado e outros (também na ordem de $35 \%$ do total da despesa com funcionalismo) que irão para o quadro do Municipio ou Municipios. - Entendemos, para resolver tais dificuldades, e por êsse esquema opinaremos, que o Estado da Guanabara pode e deve ter um só Municipio, com Prefeito nomeado pelo Governador, com serviços municipais delegados ao Estado: evitar-se-á, destarte, a luta entre dois titulares do Executivo, na mesma área (o Governador e o Prefeito, na hipótese de ser eletivo o segundo), e a partilha do quadro de servidores atualmente existente, que seria um problema emocional e politico de dificilima solução; outrossim, entendemos que a descentralização administrativa, com criação de subprefeituras ou distritos nos bairros, onde existiriam Conselhos regionais eleitos pelos habitantes em círculos de interêsses (profissionais, sociais, culturais, políticos), para a fiscalização da administração e dos serviços públicos, dinamizaria o govêrno em tôda a superfície da Guanabara e o aproximaria da coletividade carioca.

Dessa forma, com o Municipio único e a Delegação de Serviços ao Estado, realizariamos o ideal sentido da indivisão da terra Carioca, a racionalização e o barateamento da administração, e, com os Conselhos locais teríamos o povo - através de seus homens bons - entrosado no seu Govêrno, que se tornaria efetivamente democrático. E, sobretudo, não discrepariamos das formulações constitucionais prescritas para os Estados da União brasileira.

Aí estão algumas de nossas meditações e do que pensamos seja razoável, como possivel, fazer-se na organização do Estado da Guanabara. O presente memorial não é uma tese de administração pública: êle é um singelo esclarecimento de roteiro, destinado à divulgação ampla no eleitorado, e, por isso, necessàriamente breve.

De nossa capacidade, energia e honorabilidade, para pugnar por êsse roteiro, seria vanglória qualquer cousa dizermos: após têrmos passado tantos anos na Câmara local, acreditamos poder merecer o voto dos cidadãos.

É o que esperamos, solicitando, por isso, tal manifestação ide confiança.

Rio de Janeiro, agôsto de 1960. - Cotrim Neto. 